in vivo $36: 543-555(2022)$

doi:10.21873/invivo.12736

Review

\title{
Targeting the Endocannabinoid System: From the Need for New Therapies to the Development of a Promising Strategy. What About Pancreatic Cancer?
}

\author{
NIKOLAOS GARMPIS ${ }^{1,2^{*}}$, CHRISTOS DAMASKOS ${ }^{2,3^{*}}$, DIMITRIOS DIMITROULIS ${ }^{1 *}$, \\ ANNA GARMPI ${ }^{4 *}$, EVANGELOS DIAMANTIS ${ }^{5}$, PANAGIOTIS SARANTIS ${ }^{6}$, \\ VASILIKI E. GEORGAKOPOULOU ${ }^{7}$, ALEXANDROS PATSOURAS ${ }^{8}$, \\ DIONYSIOS PREVEZANOS ${ }^{3}$, ATHANASIOS SYLLAIOS ${ }^{9}$, GEORGIOS KYRIAKOS ${ }^{10}$, \\ EVANGELOS KOUSTAS ${ }^{6}$, MARKOS DESPOTIDIS ${ }^{3}$, CHRISTOS VALLILAS ${ }^{6}$, PETROS PAPALEXIS $^{4,11}$, \\ EFSTATHIOS A. ANTONIOU ${ }^{1,2}$, KONSTANTINOS KONTZOGLOU $^{1,2}$ and GREGORY KOURAKLIS ${ }^{12}$ \\ ${ }^{1}$ Second Department of Propedeutic Surgery, Laiko General Hospital, \\ Medical School, National and Kapodistrian University of Athens, Athens, Greece; \\ ${ }^{2}$ N.S. Christeas Laboratory of Experimental Surgery and Surgical Research, Medical School, \\ National and Kapodistrian University of Athens, Athens, Greece; \\ ${ }^{3}$ Renal Transplantation Unit, Laiko General Hospital, Athens, Greece; \\ ${ }^{4}$ First Department of Propedeutic Internal Medicine, Laiko General Hospital, Medical School, \\ National and Kapodistrian University of Athens, Athens, Greece; \\ ${ }^{5}$ Academic Department of Internal Medicine - Endocrinology Unit, \\ Agioi Anargyroi General Oncology Hospital of Kifisia, \\ National and Kapodistrian University of Athens, Athens, Greece; \\ ${ }^{6}$ Molecular Oncology Unit, Department of Biological Chemistry, \\ Medical School, National and Kapodistrian University of Athens, Athens, Greece; \\ ${ }^{7}$ Department of Pulmonology, Laiko General Hospital, Athens, Greece; \\ ${ }^{8}$ Second Department of Pulmonology, Sotiria Hospital, Athens, Greece; \\ ${ }^{9}$ First Department of Surgery, Laiko General Hospital, Medical School, \\ National and Kapodistrian University of Athens, Athens, Greece; \\ ${ }^{10}$ Seccion de Endocrinologia y Nutrition, Hospital General Universitario Santa Lucia, Cartagena, Spain; \\ ${ }^{11}$ Department of Biomedical Sciences, University of West Attica, Athens, Greece; \\ ${ }^{12}$ National and Kapodistrian University of Athens, Athens, Greece
}

This article is freely accessible online.

*These Authors contributed equally to this study.

Correspondence to: Dr. Christos Damaskos, MD, MSc, Ph.D., Renal Transplantation Unit, Laiko General Hospital, N.S. Christeas Laboratory of Experimental Surgery and Surgical Research, Medical School, National and Kapodistrian University of Athens, 17 Agiou Thoma Street, Athens, 11527, Greece. Mobile: +30 6948467790,e-mail: x_damaskos@yahoo.gr

Key Words: Endocannabinoid, cannabinoid, receptor, pancreatic, cancer, treatment, review.

\begin{abstract}
Pancreatic cancer is one of the most fatal malignancies, and therefore, new strategies, which aim at the improvement of the prognosis of this lethal disease, are needed. Many clinical trials have failed to improve overall survival. Nowadays, research is focused on advances provided by novel potential targets to efficiently enhance life expectancy. Cannabinoids, the active components of Cannabis sativa L., and their derivatives, have been reported as palliative adjuvants to conventional chemotherapeutic regimens. Cannabinoid effects are known to be mediated through the activation of cannabinoid receptors. To date, two cannabinoid receptors, cannabinoid receptor 1 and 2, have been cloned and identified from mammalian tissues. Cannabinoids exert a remarkable antitumoral effect on
\end{abstract}


pancreatic cancer cells, due to their ability to selectively induce apoptosis of these cells. This review strengthens the perception that cannabinoid receptors might be useful in clinical testing to prognose and treat pancreatic cancer. Many studies have tried to describe the mechanism of cell death induced by cannabinoids. The aim of this review is to discuss the effects of cannabinoid receptors in pancreatic cancer in order to provide a brief insight into cannabinoids and their receptors as pancreatic cancer biomarkers and in therapeutic strategies.

The plant Cannabis sativa L. produces approximately 60 unique compounds of bioactive lipids that have been categorized as cannabinoids. At the early stages of their discovery, it was speculated that cannabinoids induced physiological and behavioral actions via nonspecific interaction with cell membranes (1-3). Cannabinoids offer potential applications, such as being incorporated into chemotherapeutic regimens, in order to prevent nausea, pain and to stimulate appetite (4). Interestingly, cannabinoids seem to be specific, given that cancer cells can be targeted while normal cells can simultaneously be spared. Cannabinoids include compounds that have either structural, or pharmacological similarities to $\Delta 9$ tetrahydrocannabinol or bind to cannabinoid receptors $(3,5)$.

Although the knowledge concerning the pharmacology of a vast majority of the cannabinoids is poor, it is widely accepted that $\Delta 9$-tetrahydrocannabinol is the most important cannabinoid, as this compound is abundant in cannabis (6). Other relevant plant-derived cannabinoids include $\Delta 8$ tetrahydrocannabinol, which is almost as potent as $\Delta 9$ tetrahydrocannabinol, but it is found in smaller quantities. Tetrahydrocannabinol affects several biological functions by mimicking endogenous substances that activate cannabinoid receptors (5).

Cannabinoid receptors is a term to describe receptors which respond to cannabinoid drugs derived from Cannabis sativa and its biologically active synthetic analogs $(7,8)$. In particular, synthetic agonists that bind to cannabinoid receptors include $\Delta$ 9-tetrahydrocannabinol-like analogs and aminoalkylindole compounds typified by R-WIN55212. Concerning synthetic cannabinoids which have been developed in scientific laboratories, they have structural similarities to both natural and endogenous cannabinoids, such as WIN-55, 212-2, JWH-133, and $(R)$-methanandamide (9). Many years of research led to the identification of several endogenous ligands of cannabinoid receptors, such as arachidonoylethanolamide (anandamide), 2arachidonoylglycerol and 2-arachidonylglyceryl ether (noladin ether). It is possible that there are also endogenous agonists other than these eicosanoid molecules. Exogenous agonists include synthetic agonists, such as CP55940, and plant-derived natural products, such as tetrahydrocannabinol (5).

At present, research has determined the existence of two cannabinoid receptor types, cannabinoid receptor 1 (CB1) and cannabinoid receptor 2 (CB2), numbered in order of their discovery. $\mathrm{CB} 1$ and $\mathrm{CB} 2$ receptors differ in their predicted amino acid sequence, their signaling pathways and tissue distribution. Studies have shown that potent agonists and antagonists with marked selectivity for $\mathrm{CB} 1$ or $\mathrm{CB} 2$ receptors can be constructed. Likewise, $\mathrm{CB} 1, \mathrm{CB} 2$ and CB1/CB2 knockout mice can be developed $(5,8)$.

CB1 has been found in rat, mouse and human tissues and is identical in $97 \%$ to $99 \%$ of its amino acid sequence across species. Interestingly, $C B 1 \mathrm{mRNA}$ and protein are detected predominately in brain and neuronal tissue. In 1991, CB1 was first discovered in humans, and it was shown to be abundant in the brain. Moreover, it is expressed in some peripheral presynaptic nerve terminals and in a small number of extra-neural locations. CB1 receptor consists of a seventransmembrane domain receptor. Its function is associated with biological responses and information about the structure-activity relationships of ligands for interaction with this receptor. Stimulation of the $\mathrm{CB} 1$ receptors suppresses the release of neurotransmitters, such as gammaaminobutyric acid allowing the endocannabinoid system to reduce the activity of the gamma-aminobutyric acid terminal in a retrograde manner back across the synapse (11).

There is a $48 \%$ homology between CB1 and CB2. Mouse $\mathrm{CB} 2$ has been cloned and its sequence is $82 \%$ identical to that of human CB2. The mRNA of CB2 was first detected in immune tissue. Thus, it was thought that CB2 only existed in the immune system, but it has been described as being expressed in many cell types, such as natural killer cells, macrophages, monocytes, $\beta$-lymphocytes, microglial cells and inflammatory cells, in various organs of the human body, such as the brain and the gastrointestinal tract $(5,12)$. Notably, CB2 mRNA is missing from normal nervous tissue. $\Delta$ 9-Tetrahydrocannabinol-like, aminoalkylindole and eicosanoid ligands are the basic ligands of expressed CB2 protein. CB2 triggers a sustained activation of ceramide biosynthesis $(12,13)$.

Both $\mathrm{CB} 1$ and $\mathrm{CB} 2$ are coupled to toxin-sensitive Gi/o proteins. Gi proteins are heterotrimeric GTP-binding proteins that inhibit plasma membrane adenylyl cyclase. Binding to an agonist with $\mathrm{CB} 1$ or $\mathrm{CB} 2$ leads to a signaling cascade in which the activated receptor activates $\mathrm{Gi}$, which in turn inhibits adenylyl cyclase, resulting in a reduction of intracellular cyclic adenosine monophosphate (cAMP). Essentially, the classical theory of receptor occupancy and activation is a conformational induction theory that fits equivalently with Koshland's induced-fit model for enzymes. In particular, when agonist A binds to the resting-state receptor $\mathrm{R}$, conformational changes are provoked, leading to the activation of receptor $\mathrm{R} *(5,14)$.

Moreover, CB1 is coupled through $\mathrm{Gi} / \mathrm{o}$ proteins to a variety of potassium and calcium channels. As far as novel types of cannabinoid receptors are concerned, there is some 
Table I. Studies focused on cannabinoids as potential agents against pancreatic cancer as classified by different experimental systems, cannabinoid receptors, and their effects.

\begin{tabular}{|c|c|c|c|}
\hline Study (Ref) & Experimental system & Effect & Receptor \\
\hline Carracedo et al., 2006 (18) & $\begin{array}{l}\text { In vitro }(\mathrm{MiaPaCa}-2 \\
\text { Panc1 cells })\end{array}$ & $\begin{array}{l}\text { - Ceramide-dependent up-regulation } \\
\text { of stress-related genes } \\
\text { • Apoptosis }\end{array}$ & $\mathrm{CB} 2$ \\
\hline Carracedo et al., 2006 (19) & $\begin{array}{l}\text { In vitro }(\mathrm{MiaPaCa}-2 \\
\quad \text { Panc1 cells })\end{array}$ & $\begin{array}{l}\text { - Overexpression in these cell lines } \\
\text { compared with normal pancreatic tissue }\end{array}$ & $\mathrm{CB} 1, \mathrm{CB} 2$ \\
\hline \multirow[t]{2}{*}{ Michalski et al., 2006 (61) } & In vitro (human tissue & $\begin{array}{l}\text { - Inverse association with survival rate } \\
\text { of pancreatic ductal adenocarcinoma) }\end{array}$ & $\mathrm{CB} 1$ \\
\hline & In vivo (human) & - Inverse correlation with cancer pain symptoms & $\mathrm{CB} 1, \mathrm{CB} 2$ \\
\hline \multirow[t]{2}{*}{ Brandi et al., 2009 (71) } & In vitro (Panc1 cells) & $\begin{array}{c}\cdot \text { Collapse of the keratin cytoskeleton } \\
\cdot \text { Cell death }\end{array}$ & CB2 \\
\hline & In vitro (Panc1 cells) & - Antiproliferative effects & $\mathrm{CB} 1, \mathrm{CB} 2$ \\
\hline Donadelli et al., 2011 (66) & $\begin{array}{c}\text { In vitro }(\mathrm{PaCa} 44, \mathrm{PaCa} 3, \\
\text { Panc } 1, \mathrm{CFPAC} 1, \mathrm{~T} 3 \mathrm{M} 4 \text { and } \\
\text { MiaPaCa } 2 \text { cell lines })\end{array}$ & $\begin{array}{c}\text { - Inhibition of pancreatic } \\
\text { adenocarcinoma cell growth } \\
\bullet \text { Increase of ROS } \\
\text { - Inhibition of apoptosis induced } \\
\text { by gemcitabine }\end{array}$ & $\mathrm{CB} 1, \mathrm{CB} 2$ \\
\hline Fogli et al., 2013 (60) & $\begin{array}{l}\text { In vitro }(\mathrm{MiaPaCa}-2 \text { cells }) \\
\text { In vitro }(\mathrm{MiaPaCa}-2 \text { cells })\end{array}$ & $\begin{array}{l}\text { - Cell death } \\
\text { - Cytotoxicity }\end{array}$ & $\begin{array}{c}\mathrm{CB} 1 \\
\mathrm{CB} 1, \mathrm{CB} 2\end{array}$ \\
\hline Dando et al., 2013 (80) & In vitro (Panc1 cells) & $\begin{array}{c}\text { - Increase of AMPK phosphorylation } \\
\bullet \text { Autophagy } \\
\bullet \text { Increase of ROS production } \\
\text { - Increase of tumor-suppressor PTEN }\end{array}$ & $\mathrm{CB} 1, \mathrm{CB} 2$ \\
\hline \multirow[t]{2}{*}{ Guo et al. 2018 (62) } & In vivo (mouse) & $\begin{array}{l}\text { - Binding of fluorescent substance NIR760-XLP6 } \\
\text { to CB2 and earlier imaging of the cancer }\end{array}$ & $\mathrm{CB} 2$ \\
\hline & In vitro (Panc1 cells) & $\begin{array}{l}\text { - Binding of fluorescent substance NIR760-XLP6 } \\
\text { to CB2 and earlier imaging of the cancer }\end{array}$ & $\mathrm{CB} 2$ \\
\hline \multirow[t]{2}{*}{$\begin{array}{l}\text { Yasmin-Karim et al., } \\
2018(88)\end{array}$} & In vitro (Panc-02 cells) & $\begin{array}{l}\text { - Apoptosis } \\
\text { - Increase of ROS production } \\
\text { - DNA damage through radiation }\end{array}$ & NR \\
\hline & $\begin{array}{l}\text { In vivo (mouse) (simultaneous use } \\
\text { of smart radiotherapy materials } \\
\text { and cannabinoids) }\end{array}$ & $\begin{array}{l}\text { - Inhibition of tumor growth } \\
\text { - Induction of apoptosis } \\
\text { - Improvement of survival }\end{array}$ & NR \\
\hline Luongo et al., 2020 (63) & $\begin{array}{l}\text { In vitro (Panc1 cells and } \mathrm{MiaPaCa}-2) \text {, } \\
\text { co-administration of } \mathrm{O}_{2} / \mathrm{O}_{3}\end{array}$ & $\begin{array}{l}\text { - Induction of apoptosis } \\
\text { - Reduction of cell viability } \\
\text { - Reduction of cell migration } \\
\text { - Increased chemosensitivity } \\
\text { - Induction of chemotoxicity }\end{array}$ & $\mathrm{CB} 1, \mathrm{CB} 2$ \\
\hline \multirow[t]{2}{*}{ Aizikovich, 2020 (68) } & In vitro (PANC-1 and AsPC-1 cell lines) & $\begin{array}{l}\text { - Induction of cytotoxicity, } \\
\text { especially with ALAM108 }\end{array}$ & NR \\
\hline & $\begin{array}{l}\text { In vivo (human pancreatic tumor cells } \\
\text { xenografted in nude female mice) }\end{array}$ & $\begin{array}{l}\cdot \text { Weight gain } \\
\text { - Reduction of tumor volume and size }\end{array}$ & NR \\
\hline \multirow[t]{2}{*}{ Yang et al., 2020 (83) } & In vitro (pancreatic cell lines) & $\begin{array}{l}\text { - Reduction of interaction between } \\
\text { pancreatic cells and stromal cells } \\
\text { - Increase of anticancer immunity } \\
\text { - Inhibition of cell proliferation }\end{array}$ & NR \\
\hline & In vivo (mice) & - Suppression of pancreatic tumor & NR \\
\hline
\end{tabular}

AMPK: AMP-activated protein kinase; CB1: cannabinoid receptor 1; CB2: cannabinoid receptor 2; NR: not reported; PTEN: phosphatase and tensin homologue; ROS: reactive oxygen species.

preliminary evidence for their existence based on multiple criteria such as primary structure homology, signal transduction mechanisms and biological functions (5). Additionally, in 2007, Ryberg et al. reported a new cannabinoid receptor called $\mathrm{G}$ protein-coupled receptor 55 (GPR55) which binds to and is activated by CP55940 with potential action on the brain (15). Shi et al. confirmed this action, explaining how GPR55 mediates anxiolytic-like effects in the medial orbital cortex of mice (16). This effect in conjunction with analgesia, appetite regulation and antiemetic actions are referred to as palliative methods for symptoms of malignancies, with potential use as a new 


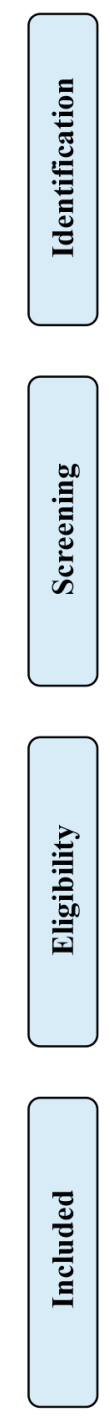

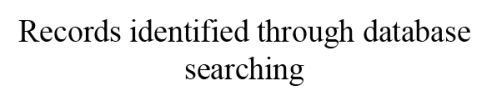

Additional records identified through other sources $(\mathrm{n}=0)$
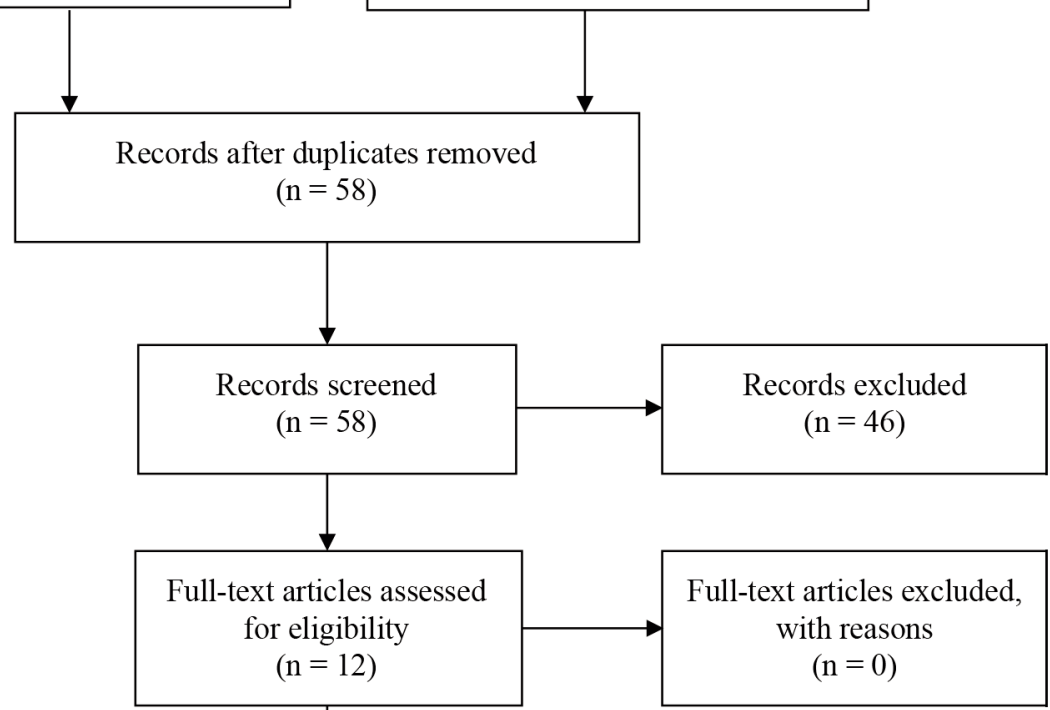

Studies included in qualitative synthesis $(\mathrm{n}=12)$

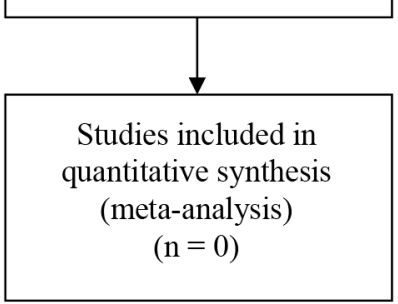

Figure 1. PRISMA flow chart for the current study.

treatment of pancreatic cancer and that is discussed extensively below.

\section{Materials and Methods}

A review of the literature was conducted through the use of the PubMed database and Cochrane library in order to identify articles regarding in vitro and in vivo studies of cannabinoid use in pancreatic cancer. Specifically, our research was performed by using key words, separately and in various combinations, such as cannabinoid, receptor, cancer, pancreatic and treatment. Furthermore, we checked the references from all articles found aiming to include any other eligible studies. The initial research identified 60 articles. After removal of duplicates, 58 remained. The remaining articles were screened and 46 were excluded for various reasons, e.g., some of them were only abstracts, whereas others were not completely relevant to the topic. Publications in non-English language were also excluded. Finally, 12 full-text articles were included (Table I). The inclusion process is shown in Figure 1.

\section{Results}

Cannabinoids against cancer. Cancer is a group of diseases characterized by abnormal cell growth and their potential to invade or spread. This uncontrolled division is caused by DNA mutations and damage, cell-cycle perturbations, and changes in apoptotic mechanisms. Thus, cancer treatment decisions rely on genetics and clinical pharmacology. In particular, molecules that modulate apoptosis in order to maintain steady-state cell growth can be beneficial agents for targeted cancer treatment. These modifications affect 

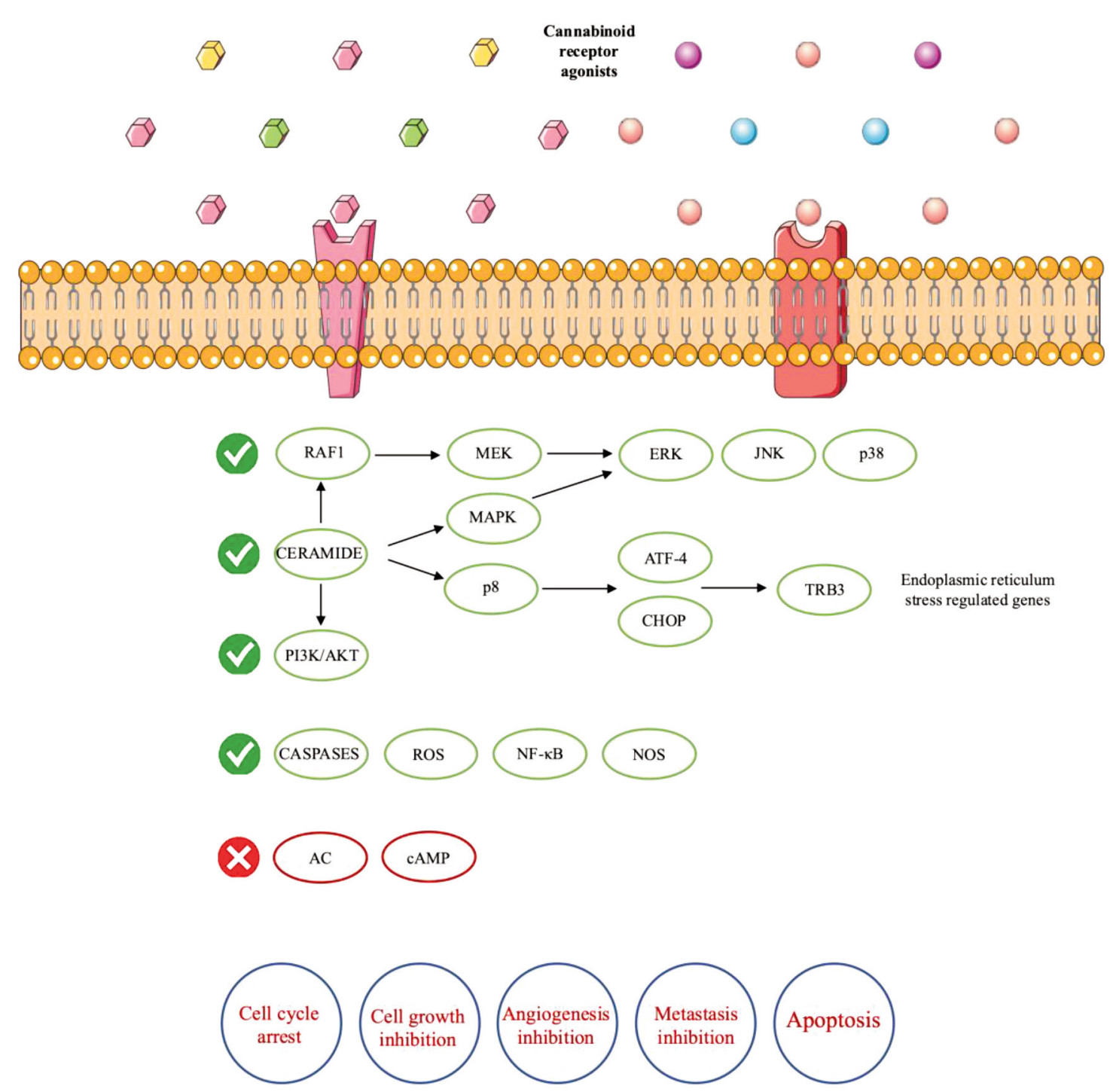

Figure 2. Mechanism of actions and anticancer effects of cannabinoid receptors. AC: Adenylyl cyclase; AKT: protein kinase B also known as AKT; ATF-4: Activating transcription factor 4; cAMP: cyclic adenosine monophosphate; CHOP: C-homologous protein; ERK: extracellular-signalregulated kinase; JNK: c-Jun N-terminal kinase; MAPK: mitogen-activated protein kinase; MEK: mitogen-activated protein kinase kinase; NF-kB: nuclear factor kappa-light-chain-enhancer of activated B-cells; NOS: nitric oxyde synthase; PI3K: phosphatidylinositol-4,5-bisphosphate 3-kinase; ROS: reactive oxygen species; TRIB3: Tribbles homolog 3.

signaling intermediates in the apoptotic cascade to induce apoptosis. Hence, given the incidence and the severity of these diseases, novel therapeutic targets need to be identified in order to combat cancer. Research into the molecular basis of cancer shows that cannabinoid receptors are promising targets.

The antiproliferative potential of cannabinoids was first reported in the early 1970s by Munson et al. It was shown that oral administration of tetrahydrocannabinol in mice inhibits Lewis lung adenocarcinoma tumor growth (17). Later, in the 1990s, studies reported that either endogenous, or synthetic cannabinoids induce antitumor effects on a wide spectrum of tumor cells in culture. In particular, it was found that in several types of cancer cells such as glioma, lymphoma, prostate, breast, pancreatic and skin cancer cells, cannabinoids reduced tumor size and induced apoptosis ( 9 , 18-22). Studies in animal tumor models, such as Wistar rats inoculated with $\mathrm{C} 6$ gliomas, and xenografts in athymic nude mice implanted with KiMol or MBA-MD-231 breast cancer cells, found that cannabinoid receptor agonists exerted antiproliferative actions (22). As a variety of biochemical and pharmacological approaches showed, these antitumor 
effects require the efficiency of $\mathrm{CB} 1$ and $\mathrm{CB} 2$. Elective cannabinoid receptor agonists and antagonists, which ligate to $\mathrm{CB} 1$ and $\mathrm{CB} 2$, can be used in order to study their expression and their mode of action (apoptotic or stimulatory) in malignant cells. However, at certain doses and in specific cellular contexts, some cannabinoids have been reported to induce the proliferation of cancer cells in vitro (23).

As was mentioned above, cannabinoid receptors are activated by specific G-protein coupling with cannabinoids. This binding induces several cellular pathways, as cAMPprotein kinase A pathway is inhibited and the activity of $\mathrm{Ca}^{2+}$ and $\mathrm{K}^{+}$channels is modulated. These changes lead to the inhibition of neurotransmitter release. Moreover, CB1 participates in a variety of different cellular signaling pathways that affect the control of cell fate. In particular, CB1 receptor coupling urges the activation of mitogenactivated protein kinase (MAPK) cascades, such as the extracellular-signal-regulated kinase (ERK), the stressactivated kinases Jun amino-terminal kinase (JNK) and p38 MAPK (25-29). These signaling cascades exert dominant roles in the regulation of cell proliferation and differentiation. Cannabinoid-induced MAPK stimulation has been reported in neural cell lines, primary neural cells, lymphoid cells, vascular endothelial cells, and Chinese hamster ovary cells that were transfected with cannabinoid receptor complementary DNAs $(10,24-26,28)$. On the other hand, an in vitro study in a neuronal-like cell line showed that CB1 receptor activation attenuates ERK (29).

Furthermore, cannabinoid receptors participate in the activation of the phosphatidylinositol 3-kinase (PI3K)-AKT serine/threonine kinase 1 (AKT) survival pathway (30-32). Particularly, the phosphorylation of AKT induces the inhibition of nuclear translocation of forkhead transcription factors $(33,34)$. As a result, the expression of pro-apoptotic proteins is prevented. However, a study reported that cannabinoid receptors negatively regulated AKT activation. Some systems showed that PI3K is an upstream component of cannabinoid-induced ERK activation, while others reported contradictory results $(35,36)$. Moreover, some conflicting data claim that nuclear factor kappa-light-chainenhancer of activated $\mathrm{B}$ cells $(\mathrm{NF}-\mathrm{kB})$ and nitric oxide synthase (NOS) are other targets of CB1 activation, which are involved in the control of cell fate. Nevertheless, it is not clear if these components are activated or inhibited by cannabinoids $(30,37)$.

Cannabinoid receptors are also involved in the modulation of sphingolipid-metabolizing pathways. CB1 activation induces sphingomyelin breakdown, resulting in an increase in ceramide levels $(38,39)$. Ceramide is a lipid second messenger that stimulates apoptosis and cell-cycle arrest. Interestingly, these actions are not based on the G-protein structure, but they are cannabinoid receptor-dependent. It is reported that an adaptor factor associated with neutral sphingomyelinase activation (FAN) is involved (40). Furthermore, cannabinoid receptor activation has the potential to urge a sustained peak of ceramide expression through enhanced de novo synthesis $(32,39)$.

Overall, cannabinoid receptors are implicated in antitumor effects by a variety of different mechanisms, as their activation stimulates transformed-cell death, inhibits transformed-cell proliferation and limits tumor angiogenesis and metastasis. As mentioned above, apoptosis is induced by de novo ceramide accumulation, sustained ERK activation and AKT inhibition (34, 41) (Figure 2). In glioma cells, ceramide levels are increased after cannabinoid receptor activation (41). This increase induces both the activation of RAF1-mitogen-activated protein kinase kinase (MEK)-ERK signaling cascade and the AKT inhibition. It is known that ERK activation stimulates cell proliferation. In any case, many factors can affect the relation between ERK activation and cell fate, given that prolonged ERK stimulation mediates cell-cycle arrest and even cell death (42). Mimeault et al. reported that in prostate tumor cells, pharmacological inhibition of de novo ceramide synthesis led to prevention of cannabinoid-induced cell death (43).

A study on breast cancer cells found that $\mathrm{CB} 1$ receptor activation induced cell-cycle arrest at the $\mathrm{G}_{1}-\mathrm{S}$ transition by inhibiting adenylyl cyclase and the cAMP signaling cascade. Given that the phosphorylation of protein kinase A reduces RAF1 expression, cannabinoid receptors block the inhibition of RAF1. As a result, the RAF1-MEK-ERK pathway is stimulated (44). Corresponding research in thyroid epithelioma cells transformed with the Kirsten rat sarcoma (KRAS) oncogene showed that $\mathrm{CB} 1$ receptor activation also blocks the cell cycle at the $\mathrm{G}_{1}-\mathrm{S}$ transition (45). However, the underlying mechanisms of cannabinoid action on the cell cycle remain obscure. Similar results of cell-cycle arrest following cannabinoid receptor activation have been reported in skin and prostate cancer cells. In these studies, growthfactor-receptor signaling is inhibited $(43,46)$. It is likely that a general underlying mechanism of cannabinoid antitumor action exists.

Angiogenesis is a very important process that allows tumors to grow beyond a minimal size. Therefore, the prevention of the angiogenic process is an extremely promising approach in order to eradicate tumors (47). Studies in mice with glioma or skin carcinoma showed that cannabinoid administration induced the modification of vascular hyperplasia into blood vessels that are characterized by small and differentiated capillaries (46). These modifications are associated with reduced expression of pro-angiogenic cytokines, such as vascular endothelial growth factor (46-48). Moreover, in vascular endothelial cells, cannabinoid receptor stimulation restrained cell migration and survival. In mice injected with lung cancer 
cells, cannabinoid receptor activation inhibited tumor metastasis (48). This might be a result of diminished activity and expression of matrix metalloproteinase 2, an enzyme that induces tissue proteolysis during angiogenesis and metastasis (46).

It is understandable that cannabinoids have been reported as useful antitumor agents in animal cancer models. Concerning toxicity, studies claim that cannabinoids have a good safety profile and offer relief to patients with cancer. However, their antitumor activity in humans has not been demonstrated. The Spanish Ministry of Health has approved a phase I clinical trial which aims at investigating the effect of administration of $\Delta 9$ - tetrahydrocannabinol on the growth of recurrent glioblastoma multiforme. Guzman et al. found $\Delta$ 9-tetrahydrocannabinol to have antiproliferative action on tumor cells (49). However, Massi et al. reported that cannabidiol treatment led to stimulation of apoptosis in glioma cells. Moreover, they showed that the same treatment eliminated tumor growth through activation of caspases and reactive oxygen species (ROS) (50). Although the mechanisms of action of cannabinoids remain obscure, it is clear that cannabinoid receptors have a prominent role in treatment of cancer.

Cannabinoids against pancreatic cancer. Pancreatic cancer has evolved as one of the deadliest diseases. Pancreatic cancer accounts for about $3 \%$ of all cancer in the United States and about $7 \%$ of all cancer-related deaths (51). According to the Surveillance Epidemiology and End Results program, the 5-year survival rate of patients with pancreatic cancer is $4 \%$. This figure is the lowest of all cancer types $(52,53)$. However, the high mortality rate is a result of limited early diagnosis, ineffective chemotherapy, and poor radiotherapy response. Moreover, $50 \%$ of patients with early pancreatic cancer do not show symptoms. After the diagnosis, the 4-year survival rate can rise to $78 \%$ after resection of pancreatic cancer with a size smaller than $2 \mathrm{~cm}$ (54). The standard chemotherapy for pancreatic cancer is gemcitabine (55). Unfortunately, the efficacy of this current therapy is limited due to the complicated tumor microenvironment, which hinders efficient drug delivery to the cell target (56). Therefore, the scientific community is trying to target the molecular mechanisms of pancreatic cancer $(57,58)$. For instance, activation of KRAS oncoprotein, inactivation of $\mathrm{p} 16^{\mathrm{INK} 4 \mathrm{~A}}$, overexpression of cyclo-oxygenase- 2 and loss of p53 effects are the main targets of the molecular pathology of pancreatic cancer (53, $54,59)$. Recent therapeutic strategies include combinations of these compounds and gemcitabine in order to enhance the efficacy of pancreatic cancer treatment $(54,57)$.

An in vitro study investigated the antitumor effects of $\mathrm{CB}$ receptors and their potential role in the human pancreatic cancer cell line MIA PaCa-2 (60). According to this study, cannabinoid derivatives were cytotoxic via a receptorindependent mechanism. In particular, both selective CB1 and $\mathrm{CB} 2$ receptors agonists and antagonists induced a significant cytotoxic effect. The absence of CB2 receptors clearly prevented a potential role of these receptors in cannabinoid cytotoxicity. Moreover, CB1 receptor agonist and antagonist, at nanomolar concentrations, did not significantly alter cell viability in serum-free medium, which is a condition that avoids non-specific interactions with serum components. Given that cannabinoids are lipophilic components, it is understandable that cytotoxicity can arise by their crossing the cell membrane and rupturing cellular networks, resulting in cell death. Internucleosomal degradation of DNA by CB1 antagonist $N$-(piperidin-1-1yl)5-(4-iodophenyl)-1-(2,4-dichlorophenyl)-4-methyl-1Hpyrazole-3-carboxamide (AM251) showed that apoptosis might contribute to its antitumor effect. AM251 also induced a significant time-response action on caspase $3 / 7$, indicating that these two enzymes of apoptosis were a target of cannabinoids. It is possible that apoptosis might be mediated via a caspase-dependent pathway. The gene-expression profile of MIA PaCa-2 cells after AM251 treatment was examined by microarray analysis and AM251 was found to act on cell cycle-related pathways, as well as on critical steps in cell proliferation including Janus kinase (JAK)/signal transducers and activators of transcription (STAT) and MAPK signaling cascades. We should mention that in that study, AM251 was found to synergistically enhance the anticancer activity of 5-fluorouracil, which is a very common agent used in the treatment of pancreatic cancer (57). Hence, AM251 is highlighted as a novel compound for pancreatic cancer therapy (60).

In recent years, there has been increasing interest in cannabinoids as a therapeutic regiment against pancreatic cancer $(18,19,60)$. About $95 \%$ of clinical cases of pancreatic cancer are ductal adenocarcinomas. Michalski et al. studied immunoreactivity for $\mathrm{CB} 1$ and $\mathrm{CB} 2$ receptors, as well as for the endocannabinoid metabolizing enzymes fatty acid amide hydrolase (FAAH) and monoacyl glycerol lipase (MGLL) in human tissues of pancreatic ductal adenocarcinoma. Interestingly, significant variation was reported in receptors, and FAAH and MGLL levels between healthy people and patients suffering from pancreatic cancer (61). As CB1 and CB2 receptors levels were up-regulated in pancreatic cancer, it is assumed that cannabinoid receptors have dominant role in pancreatic carcinogenesis. We should mention that in their study, endocannabinoid levels in pancreatic cancer tissues did not change, possibly due to the strong desmoplastic reaction in pancreatic cancer. Researchers found an inverse association between CB1 receptor quantity and survival and an association between FAAH or MGLL levels in cancer cells and survival rate. On the contrary, other studies claim that cannabinoids are 
involved in antiproliferative activities on pancreatic cancer growth. In any case, the heterogeneous expression patterns of cannabinoid receptors indicate their potential use as clinical biomarkers $(18,60,62)$. Guo et al. showed that $\mathrm{CB} 2 \mathrm{R}$ is overexpressed in both human pancreatic adenocarcinoma tissues and cell lines. Fluorescent substances such as NIR760-XLP6 binding to CB2R can permit early recognition of pancreatic cancer tissue and earlier diagnosis (62). Michalski et al. also reported that cannabinoid receptors may be associated with the development of pancreatic cancer pain, as both CB1 and $\mathrm{CB} 2$ receptor expression were inversely correlated with pain symptoms of patients. Nevertheless, given that there was no association between FAAH/MGLL levels and pain scores, endocannabinoid inactivation through FAAH or MGLL is probably not involved in pancreatic cancer pain (61).

Other studies investigated cannabinoid receptors in pancreatic cancer both in vitro and in vivo $(18,63)$. Researchers showed that cannabinoid receptors are more highly expressed in human pancreatic tumor cell lines and tumor biopsies than in normal pancreatic tissue. In vitro studies in MiaPaCa2 and Panc1 cell lines reported that cannabinoid administration led to apoptosis, reduced cell viability and augmented the levels of ceramide and caspase 3. The combination of cannabinoid and $\mathrm{O}_{2} / \mathrm{O}_{3}$ induced cytotoxicity and augmented chemosensitivity to gemcitabine and paclitaxel (63). Moreover, mRNA levels of the p8 protein, which is associated with stress, were up-regulated (19). Interestingly, when CB2 receptor was blocked, all the above effects were prevented (18). These results agree with other observations that had shown that CB2 receptor is associated with the anticancer effect of cannabinoids in gliomas and lymphomas, as well as skin and prostate carcinomas $(9,46,64,65)$. CB2-selective activation is not related to the typical marijuana-like psychoactive effects that we meet in CB1 receptor activation (5). Researchers found that $\mathrm{CB} 2$ receptor-dependent accumulation of de novosynthesized ceramide induced p8 up-regulation. p8 was involved, via its down-stream endoplasmic reticulum stressrelated targets, in the stimulation of activating transcription factor 4 (ATF-4) and proapoptotic protein TRB3 in apoptosis stimulated by $\Delta 9$-tetrahydrocannabinol. Furthermore, study in tumor xenografts showed that cannabinoid treatment reduced tumor growth and inhibited the spreading of pancreatic cancer cells. Similarly, to the in vitro studies, apoptotic death and increase of TRB3 expression was observed in pancreatic tumor cells, while there were no changes in normal tissue (18). Hence, CB2 receptor is reported to induce apoptosis of pancreatic tumor cells, setting the basis for a novel therapeutic approach for the treatment of pancreatic malignancy.

A recent study investigated the correlation of gemcitabine with the synthetic cannabinoids arachidonylcyclopropamide
(ACPA) or W405833 (GW) (66). ACPA is a highly selective agonist for $\mathrm{CB} 1$ receptor, while $\mathrm{GW}$ is a selective agonist for $\mathrm{CB} 2$ receptor (67). Gemcitabine induced both $\mathrm{CB} 1$ and $\mathrm{CB} 2$ receptors via a nuclear factor-kB (NF-kB)-dependent molecular mechanism. The co-treatment prevented pancreatic adenocarcinoma and cell growth, as it induced ROS production. As a result, endoplasmic reticulum stress and autophagic cell death were provoked. Free radical scavenger $N$-acetyl-cysteine and the specific NF-kB inhibitor BAY 11-7085 prevented the antitumor synergism, indicating that the stimulation of ROS by gemcitabine and cannabinoid co-treatment, and of NF-kB by gemcitabine were essential for these actions. In human pancreatic tumor cells xenografted in nude mice, combined treatment significantly prevented tumor growth. Similar effects on the tumor size and volume were observed in another study, in which ALAM027 and ALAM108, two new cannabinoid derivatives were used in human pancreatic female mice bearing tumor cell xenografts. In the same study, ALAM108 demonstrated higher cytotoxicity at lower concentrations against pancreatic cancer cell lines (68). Furthermore, cannabinoid treatment activated transcriptional factor X-box-binding protein-1 (XBP-1) splicing, glucose-regulated protein 78 (GRP78) and CCAAT/enhancer-binding protein $(\mathrm{C} / \mathrm{EBP})$ as well as homologous protein (CHOP) gene induction $(69,70)$. These genes are the molecular switch that stimulate autophagic or apoptotic cell death signals. It is noteworthy that these endoplasmic reticulum stress-related genes were also enhanced by gemcitabine. This evidence shows that these genes might be involved in gemcitabine/cannabinoid cotreatment. We should mention that according to Donadelli et al., although ACPA or GW induced cell-cycle arrest at the $\mathrm{G}_{1}$ phase, they did not induce apoptosis. In addition, cannabinoid treatment partially, but significantly, inhibited apoptosis stimulated by gemcitabine (66). These data are contradictory to those of Carracedo et al. but it is possible that this discrepancy is a result of the different cannabinoid receptor agonists that were used (18).

Another study of Panc1 cells showed that treatment for 12 $\mathrm{h}$ with increasing amounts ACPA or GW had antiproliferative effects. GW inhibited tumor growth significantly and more intensively than ACPA. Moreover, treatment of Panc1 cells with cannabinoids led to the down-regulation of phosphorylated alanine aminopeptidase (ANPEP) (71). ANPEP is a zinc-dependent metallo-exopeptidase found on the surface of tumor cells. ANPEP degrades the extracellular matrix and, as a result, it induces tumor invasion, angiogenesis and metastasis (72). It constitutes a transcriptional target of RAS signaling pathways. ANPEP inhibitors have been reported to be effective anticancer agents (73). It is noteworthy that ANPEP has been proposed as a novel prognostic biomarker for patients with pancreatic cancer (74). 
Proteomic investigation showed that cannabinoid treatment induced several isoforms of phospho-keratins 18 (KRT18) (SSP6411, SSP6402, SSP6410) (71). KRT18 is a filament protein associated with mitosis, apoptotic death, signaling pathways and invasion. Phosphorylation of KRT18 at Ser52 is necessary for filament reconstruction at cell-cycle arrest, as during apoptosis; intermediate filaments reorganize into granular structures enriched for phosphorylated KRT18 (75). Phosphorylation of KRT19 at Ser33 is associated with 14-3-3 proteins but it does not seem essential for apoptosis (76). GW strongly induced KRT18 phosphorylation both at Ser52 and Ser53, while total KRT18 expressed was downregulated (71). Presumably, CB2 receptor activation, by augmenting KRT18 phosphorylation, induces the collapse of the keratin cytoskeleton and cell death (77).

AMP-activated protein kinase (AMPK) plays an important role in autophagy, as it inhibits mammalian target of rapamycin complex 1 (mTORC1), the major regulator of cell growth (78). AMPK is a crucial molecule in the autophagic pathway induced by cannabinoids (79). Dando et al. found that ACPA and GW synthetic cannabinoids induced the activation of AMPK in pancreatic adenocarcinoma cells, as they increased the cellular AMP/adenosine triphosphate (ATP) ratio (80). Cannabinoid treatment reduced the phosphorylation level of p70S6K, a direct target of mTORC1, as well as increasing AMPK phosphorylation. Furthermore, AMPK is reported to be an intracellular energy sensor and plays an active role in maintaining intracellular homeostasis during stress challenges (81). For instance, oxidative stress has been found to induce AMPK (82). ROS were essential for the increase in AMP/ATP ratio, which in turn led to the activation of AMPK by cannabinoids and as a result to autophagy. Their study reported that treatment with either ACPA or GW elevated the nicotinamide adenine dinucleotide $(\mathrm{NADH})$ level and this increase was prevented in presence of the radical scavenger $\mathrm{N}$-acetyl-L-cysteine. These results suggest that ROS production induced by cannabinoids might disrupt the electron transport chain, which in turn inhibits the Krebs cycle, leading to NADH accumulation and inhibition of oxidative phosphorylation, which could further elevate the ROS level (80). The p-21-activated kinase 1 mediated pathway is responsible for the anticancer effects of cannabinoids. Yang et al. conducted a study in which they tested the antitumor effects of cannabinoids in cell lines and mouse models. The p-21 pathway is particularly related to the actions of the KRAS pathway. Cannabinoids act through the inhibition of these pathways. Thus, the interaction between pancreatic cells and pancreatic stromal cells was reduced, leading to reduction of the proliferation of cancer cells and of tumor growth. Furthermore, antitumor immunity was restored through the down-regulation of programmed deathligand 1 (PD-L1), leading to a better immune response and reduction of tumor size (83).
Concomitantly, endocannabinoid treatment increased expression of phosphatase and tensin homolog (PTEN), which is a tumor suppressor mutated in different types of human cancer. PTEN is a major regulator of AKT, which, in turn, up-regulates c-MYC (84). Recently, it has been shown that c-MYC is involved in the transcription of genes that lead to the expression of kinase isoform M2 (PKM2) $(85,86)$. PKM2 is expressed in cancer and promotes aerobic glycolysis $(85,87)$. Cannabinoids were shown to determine the down-regulation of PKM2, via the inhibition of c-MYC (80). Overall, in pancreatic adenocarcinoma cells treated with cannabinoids, autophagy that was induced by cannabinoids is highly associated with inhibition of energetic metabolism, which, in turn, is related to cannabinoiddependent ROS production.

All the studies mentioned above demonstrated different oncogenic pathways which can be affected through cannabinoid receptors. The action of cannabinoids might be potentiated by the use of other chemotherapeutic agents or modalities in order to exert a synergistic antitumor activity (65). Yasmin-Karim et al. showed in both in vitro and in vivo studies that the use of cannabinoids against pancreatic malignancy can also be potentiated through the use of radiation and can prolong survival (88). As a result, their simultaneous use with chemotherapy and radiation can probably reduce the side-effects of both and improve the clinical outcome. All these studies offer promising results in the field of pancreatic cancer treatment. Thus, further research should take place in order to explain the mechanisms of action of cannabinoids and prove their clinical significance against pancreatic malignancy, especially in combination with other therapeutic methods.

\section{Conclusion}

In recent decades, the genetic and pharmaceutical manipulation of the cannabinoid system has gained significant interest in the emergence of new drugs and their actions, both in cancer and various diseases. Natural and synthetic analog of the marijuana plant Cannabis sativa L. affect several human diseases such as neurological, cardiovascular, and autoimmune disorders, pain, inflammation, and diabetes as well as cancer. As a result, the medicinal use of cannabis has potential against a variety of diseases; the US Food and Drug Administration has already approved the application of certain relative drug regimens (89).

Several effects of cannabinoids are mediated through the activation of cannabinoid receptors. Two cannabinoid receptors have been identified and cloned from mammalian tissues: the 'central' CB1 receptor and the 'peripheral' CB2 receptor, while a few more are under investigation. These receptors and their antagonists are proving to be meaningful as they are able to have a targeted impact on cancer cells whilst sparing normal cells. The differential expression of 
CB1 and CB2 receptors in different cell lines is justified by the variation of the effects of cannabinoids. Low expression of cannabinoid receptors may induce cell proliferation and metastasis, as the antitumor immune response is suppressed, while overexpression of cannabinoid receptors could have antitumor effects.

Concerning pancreatic cancer, the cannabinoid system does not seem to play a relative role in cell proliferation. However, it was found that the $\mathrm{CB} 1$ receptor antagonist AM251 might be an important compound for the development of promising diarylpyrazole derivatives active against pancreatic cancer (60). Moreover, cannabinoid administration induced apoptosis of pancreatic tumor cells. In particular, apoptosis was a result of CB2 receptor activity and ceramide-dependent up-regulation of p8, ATF-4 and TRB3 stress-related genes (18). It is understandable that the observed effects of these two studies are contradictory. However, it is clear that cannabinoids have therapeutic potential for the treatment of pancreatic cancer and probably diagnostic value. Unfortunately, we cannot completely explain these effects, as the knowledge about the mechanism of action of cannabinoid receptors is limited.

In any case, there is evidence that cannabinoid receptors should be investigated as chemotherapeutic agents either as combination therapy boosting palliative treatment, or as monotherapy. In future clinical studies, researchers should evaluate different combinations of cannabinoid agents along with chemotherapeutic regimens and clarify the optimum ratio in order to achieve down-regulation of malignant cells and avoid tumor cell proliferation. Hence, further studies are required to elucidate the exact mechanism of action of cannabinoid receptors and their possible future potential against pancreatic cancer. After all, the clarification of the aforementioned factors and the creation of more evidencebased data are preconditions for the approval of such cannabinoid-based medicinal products by the Food and Drug Administration.

\section{Conflicts of Interest}

All the Authors declare that there are no conflicts of interest.

\section{Authors' Contributions}

Nikolaos Garmpis, Christos Damaskos and Dimitrios Dimitroulis designed the study. Nikolaos Garmpis, Christos Damaskos, Dimitrios Dimitroulis and Anna Garmpi wrote the article. Nikolaos Garmpis, Christos Damaskos, Anna Garmpi, Evangelos Diamantis, Panagiotis Sarantis, Vasiliki E. Georgakopoulou, Alexandros Patsouras, Athanasios Syllaios, Georgios Kyriakos, Evangelos Koustas, Christos Vallilas and Petros Papalexis collected the data. Christos Damaskos, Panagiotis Sarantis, Efstathios A. Antoniou, Konstantinos Kontzoglou and Dimitrios Dimitroulis offered scientific advice. Dionysios Prevezanos and Markos Despotidis revised the article. Gregory Kouraklis critically revised the article and was the supervisor.

\section{References}

1 Robson PJ: Therapeutic potential of cannabinoid medicines. Drug Test Anal 6(1-2): 24-30, 2014. PMID: 24006213. DOI: 10.1002/dta. 1529

2 Pertwee RG: Cannabis and cannabinoids: pharmacology and rationale for clinical use. Forsch Komplementarmed 6 Suppl 3: 12-15, 1999. PMID: 10575283. DOI: 10.1159/000057150

3 Howard P, Twycross R, Shuster J, Mihalyo M and Wilcock A: Cannabinoids. J Pain Symptom Manage 46(1): 142-149, 2013. PMID: 23707385. DOI: 10.1016/j.jpainsymman.2013.05.002

4 Malik Z, Baik D and Schey R: The role of cannabinoids in regulation of nausea and vomiting, and visceral pain. Curr Gastroenterol Rep 17(2): 429, 2015. PMID: 25715910. DOI: 10.1007/s11894-015-0429-1

5 Howlett AC, Barth F, Bonner TI, Cabral G, Casellas P, Devane WA, Felder CC, Herkenham M, Mackie K, Martin BR, Mechoulam $\mathrm{R}$ and Pertwee RG: International Union of Pharmacology. XXVII. Classification of cannabinoid receptors. Pharmacol Rev 54(2): 161-202, 2002. PMID: 12037135. DOI: 10.1124/pr.54.2.161

6 Gaoni Y and Mechoulam R: The isolation and structure of delta1-tetrahydrocannabinol and other neutral cannabinoids from hashish. J Am Chem Soc 93(1): 217-224, 1971. PMID: 5538858. DOI: $10.1021 / \mathrm{ja} a 0730 \mathrm{a} 036$

7 Herkenham M, Lynn AB, Johnson MR, Melvin LS, de Costa BR and Rice KC: Characterization and localization of cannabinoid receptors in rat brain: a quantitative in vitro autoradiographic study. J Neurosci 11(2): 563-583, 1991. PMID: 1992016.

8 Howlett AC, Bidaut-Russell M, Devane WA, Melvin LS, Johnson MR and Herkenham M: The cannabinoid receptor: biochemical, anatomical and behavioral characterization. Trends Neurosci 13(10): 420-423, 1990. PMID: 1700516. DOI: 10.1016/0166-2236(90)90124-s

9 Sarfaraz S, Afaq F, Adhami VM and Mukhtar H: Cannabinoid receptor as a novel target for the treatment of prostate cancer. Cancer Res 65(5): 1635-1641, 2005. PMID: 15753356. DOI: 10.1158/0008-5472.CAN-04-3410

10 Talwar R and Potluri VK: Cannabinoid 1 (CB1) receptorpharmacology, role in pain and recent developments in emerging CB1 agonists. CNS Neurol Disord Drug Targets 10(5): 536-544, 2011. PMID: 21631407. DOI: $10.2174 / 187152711796235005$

11 Ohno-Shosaku T, Maejima $\mathrm{T}$ and Kano M: Endogenous cannabinoids mediate retrograde signals from depolarized postsynaptic neurons to presynaptic terminals. Neuron 29(3): 729-738, 2001. PMID: 11301031. DOI: 10.1016/s08966273(01)00247-1

12 Malfitano AM, Basu S, Maresz K, Bifulco M and Dittel BN: What we know and do not know about the cannabinoid receptor 2 (CB2). Semin Immunol 26(5): 369-379, 2014. PMID: 24877594. DOI: $10.1016 /$ j.smim.2014.04.002

13 Atwood BK and Mackie K: CB2: a cannabinoid receptor with an identity crisis. Br J Pharmacol 160(3): 467-479, 2010. PMID: 20590558. DOI: $10.1111 / j .1476-5381.2010 .00729 . x$

14 Koshland DE Jr: Enzyme flexibility and enzyme action. J Cell Comp Physiol 54: 245-258, 1959. PMID: 14411189. DOI: $10.1002 /$ jcp. 1030540420

15 Ryberg E, Larsson N, Sjögren S, Hjorth S, Hermansson NO, Leonova J, Elebring T, Nilsson K, Drmota T and Greasley PJ: The orphan receptor GPR55 is a novel cannabinoid receptor. $\mathrm{Br}$ 
J Pharmacol 152(7): 1092-1101, 2007. PMID: 17876302. DOI: 10.1038/sj.bjp.0707460

16 Shi QX, Yang LK, Shi WL, Wang L, Zhou SM, Guan SY, Zhao MG and Yang Q: The novel cannabinoid receptor GPR55 mediates anxiolytic-like effects in the medial orbital cortex of mice with acute stress. Mol Brain 10(1): 38, 2017. PMID: 28800762. DOI: 10.1186/s13041-017-0318-7

17 Munson AE, Harris LS, Friedman MA, Dewey WL and Carchman RA: Antineoplastic activity of cannabinoids. J Natl Cancer Inst 55(3): 597-602, 1975. PMID: 1159836. DOI: $10.1093 /$ jnci/55.3.597

18 Carracedo A, Gironella M, Lorente M, Garcia S, Guzmán M, Velasco G and Iovanna JL: Cannabinoids induce apoptosis of pancreatic tumor cells via endoplasmic reticulum stress-related genes. Cancer Res 66(13): 6748-6755, 2006. PMID: 16818650. DOI: 10.1158/0008-5472.CAN-06-0169

19 Carracedo A, Lorente M, Egia A, Blázquez C, García S, Giroux V, Malicet C, Villuendas R, Gironella M, González-Feria L, Piris MA, Iovanna JL, Guzmán M and Velasco G: The stressregulated protein $\mathrm{p} 8$ mediates cannabinoid-induced apoptosis of tumor cells. Cancer Cell 9(4): 301-312, 2006. PMID: 16616335. DOI: 10.1016/j.ccr.2006.03.005

20 Blázquez C, Carracedo A, Barrado L, Real PJ, Fernández-Luna JL, Velasco G, Malumbres M and Guzmán M: Cannabinoid receptors as novel targets for the treatment of melanoma. FASEB J 20(14): 2633-2635, 2006. PMID: 17065222. DOI: 10.1096/ fj.06-6638fje

21 Gustafsson K, Christensson B, Sander B and Flygare J: Cannabinoid receptor-mediated apoptosis induced by $\mathrm{R}(+)$ methanandamide and Win55,212-2 is associated with ceramide accumulation and p38 activation in mantle cell lymphoma. Mol Pharmacol 70(5): 1612-1620, 2006. PMID: 16936228. DOI: $10.1124 / \mathrm{mol} .106 .025981$

22 Ligresti A, Moriello AS, Starowicz K, Matias I, Pisanti S, De Petrocellis L, Laezza C, Portella G, Bifulco M and Di Marzo V: Antitumor activity of plant cannabinoids with emphasis on the effect of cannabidiol on human breast carcinoma. J Pharmacol Exp Ther 318(3): 1375-1387, 2006. PMID: 16728591. DOI: 10.1124/jpet.106.105247

23 Hart S, Fischer OM and Ullrich A: Cannabinoids induce cancer cell proliferation via tumor necrosis factor alpha-converting enzyme (TACE/ADAM17)-mediated transactivation of the epidermal growth factor receptor. Cancer Res 64(6): 1943-1950, 2004. PMID: 15026328. DOI: 10.1158/0008-5472.can-03-3720

24 Bouaboula M, Poinot-Chazel C, Bourrié B, Canat X, Calandra B, Rinaldi-Carmona M, Le Fur G and Casellas P: Activation of mitogen-activated protein kinases by stimulation of the central cannabinoid receptor CB1. Biochem J 312 (Pt 2): 637-641, 1995. PMID: 8526880 . DOI: $10.1042 / b j 3120637$

25 Bouaboula M, Poinot-Chazel C, Marchand J, Canat X, Bourrié B, Rinaldi-Carmona M, Calandra B, Le Fur G and Casellas P Signaling pathway associated with stimulation of CB2 peripheral cannabinoid receptor. Involvement of both mitogen-activated protein kinase and induction of Krox-24 expression. Eur J Biochem 237(3): 704-711, 1996. PMID: 8647116. DOI: 10.1111/j.1432-1033.1996.0704p.x

26 Rueda D, Galve-Roperh I, Haro A and Guzmán M: The CB(1) cannabinoid receptor is coupled to the activation of c-Jun Nterminal kinase. Mol Pharmacol 58(4): 814-820, 2000. PMID: 10999952. DOI: $10.1124 / \mathrm{mol} .58 .4 .814$
27 Derkinderen P, Ledent C, Parmentier M and Girault JA: Cannabinoids activate p38 mitogen-activated protein kinases through CB1 receptors in hippocampus. J Neurochem 77(3): 957-960, 2001. PMID: 11331425. DOI: 10.1046/j.1471-4159. 2001.00333.x

28 Liu J, Gao B, Mirshahi F, Sanyal AJ, Khanolkar AD, Makriyannis A and Kunos G: Functional CB1 cannabinoid receptors in human vascular endothelial cells. Biochem J 346 Pt 3: 835-840, 2000. PMID: 10698714.

29 Rueda D, Navarro B, Martinez-Serrano A, Guzman M and Galve-Roperh I: The endocannabinoid anandamide inhibits neuronal progenitor cell differentiation through attenuation of the Rap1/B-Raf/ERK pathway. J Biol Chem 277(48): 4664546650, 2002. PMID: 12237305. DOI: 10.1074/jbc.M206590200

30 Kokona D and Thermos K: Synthetic and endogenous cannabinoids protect retinal neurons from AMPA excitotoxicity in vivo, via activation of $\mathrm{CB} 1$ receptors: Involvement of PI3K/Akt and MEK/ERK signaling pathways. Exp Eye Res 136: 45-58, 2015. PMID: 25989217. DOI: 10.1016/j.exer.2015.05.007

31 Sánchez MG, Ruiz-Llorente L, Sánchez AM and Díaz-Laviada I: Activation of phosphoinositide 3-kinase/PKB pathway by $\mathrm{CB}(1)$ and $\mathrm{CB}(2)$ cannabinoid receptors expressed in prostate PC-3 cells. Involvement in Raf-1 stimulation and NGF induction. Cell Signal 15(9): 851-859, 2003. PMID: 12834810. DOI: $10.1016 / \mathrm{s} 0898-6568(03) 00036-6$

32 Vivanco I and Sawyers CL: The phosphatidylinositol 3-Kinase AKT pathway in human cancer. Nat Rev Cancer 2(7): 489-501, 2002. PMID: 12094235 . DOI: $10.1038 /$ nrc 839

33 Samson MT, Small-Howard A, Shimoda LM, Koblan-Huberson M, Stokes AJ and Turner H: Differential roles of CB1 and CB2 cannabinoid receptors in mast cells. J Immunol 170(10): 4953-4962, 2003. PMID: 12734338. DOI: 10.4049/jimmunol.170.10.4953

34 Gómez del Pulgar T, Velasco G, Sánchez C, Haro A and Guzmán $\mathrm{M}$ : De novo-synthesized ceramide is involved in cannabinoidinduced apoptosis. Biochem J 363(Pt 1): 183-188, 2002. PMID: 11903061. DOI: 10.1042/0264-6021:3630183

35 Galve-Roperh I, Rueda D, Gómez del Pulgar T, Velasco G and Guzmán M: Mechanism of extracellular signal-regulated kinase activation by the $\mathrm{CB}(1)$ cannabinoid receptor. Mol Pharmacol 62(6): 1385-1392, 2002. PMID: 12435806. DOI: 10.1124/mol. 62.6 .1385

36 Derkinderen P, Valjent E, Toutant M, Corvol JC, Enslen H, Ledent C, Trzaskos J, Caboche J and Girault JA: Regulation of extracellular signal-regulated kinase by cannabinoids in hippocampus. J Neurosci 23(6): 2371-2382, 2003. PMID: 12657697.

37 Zhang J, Wang N, Chen B, Wang Y, He J, Cai X, Zhang H, Wei $\mathrm{S}$ and $\mathrm{Li} \mathrm{S}$ : Blockade of Cannabinoid $\mathrm{CB} 1$ receptor attenuates the acquisition of morphine-induced conditioned place preference along with a downregulation of ERK, CREB phosphorylation, and BDNF expression in the nucleus accumbens and hippocampus. Neurosci Lett 630: 70-76, 2016. PMID: 27461790. DOI: 10.1016/j.neulet.2016.07.047

38 Hannun YA and Obeid LM: The Ceramide-centric universe of lipid-mediated cell regulation: stress encounters of the lipid kind. J Biol Chem 277(29): 25847-25850, 2002. PMID: 12011103. DOI: $10.1074 /$ jbc.R200008200

39 Sánchez C, Galve-Roperh I, Rueda D and Guzmán M: Involvement of sphingomyelin hydrolysis and the mitogen-activated protein kinase cascade in the Delta9-tetrahydrocannabinol-induced 
stimulation of glucose metabolism in primary astrocytes. Mol Pharmacol 54(5): 834-843, 1998. PMID: 9804618. DOI: $10.1124 / \mathrm{mol} .54 .5 .834$

40 Sánchez C, Rueda D, Ségui B, Galve-Roperh I, Levade T and Guzmán M: The $\mathrm{CB}(1)$ cannabinoid receptor of astrocytes is coupled to sphingomyelin hydrolysis through the adaptor protein fan. Mol Pharmacol 59(5): 955-959, 2001. PMID: 11306675. DOI: $10.1124 / \mathrm{mol} .59 .5 .955$

41 Galve-Roperh I, Sánchez C, Cortés ML, Gómez del Pulgar T, Izquierdo $\mathrm{M}$ and Guzmán $\mathrm{M}$ : Anti-tumoral action of cannabinoids: involvement of sustained ceramide accumulation and extracellular signal-regulated kinase activation. Nat Med 6(3): 313-319, 2000. PMID: 10700234. DOI: 10.1038/73171

42 Melck D, Rueda D, Galve-Roperh I, De Petrocellis L, Guzmán $\mathrm{M}$ and Di Marzo V: Involvement of the cAMP/protein kinase A pathway and of mitogen-activated protein kinase in the antiproliferative effects of anandamide in human breast cancer cells. FEBS Lett 463(3): 235-240, 1999. PMID: 10606728. DOI: 10.1016/s0014-5793(99)01639-7

43 Mimeault M, Pommery N, Wattez N, Bailly C and Hénichart JP: Anti-proliferative and apoptotic effects of anandamide in human prostatic cancer cell lines: implication of epidermal growth factor receptor down-regulation and ceramide production. Prostate 56(1): 1-12, 2003. PMID: 12746841. DOI: 10.1002/pros.10190

44 De Petrocellis L, Melck D, Palmisano A, Bisogno T, Laezza C, Bifulco $M$ and Di Marzo V: The endogenous cannabinoid anandamide inhibits human breast cancer cell proliferation. Proc Natl Acad Sci U.S.A. 95(14): 8375-8380, 1998. PMID: 9653194. DOI: $10.1073 /$ pnas.95.14.8375

45 Bifulco M, Laezza C, Portella G, Vitale M, Orlando P, De Petrocellis L and Di Marzo V: Control by the endogenous cannabinoid system of ras oncogene-dependent tumor growth. FASEB J 15(14): 2745-2747, 2001. PMID: 11687506. DOI: 10.1096/fj.01-0320fje

46 Casanova ML, Blázquez C, Martínez-Palacio J, Villanueva C, Fernández-Aceñero MJ, Huffman JW, Jorcano JL and Guzmán M: Inhibition of skin tumor growth and angiogenesis in vivo by activation of cannabinoid receptors. J Clin Invest 111(1): 43-50, 2003. PMID: 12511587 . DOI: $10.1172 /$ JCI16116

47 Kerbel R and Folkman J: Clinical translation of angiogenesis inhibitors. Nat Rev Cancer 2(10): 727-739, 2002. PMID: 12360276. DOI: $10.1038 /$ nrc905

48 Portella G, Laezza C, Laccetti P, De Petrocellis L, Di Marzo V and Bifulco M: Inhibitory effects of cannabinoid CB1 receptor stimulation on tumor growth and metastatic spreading: actions on signals involved in angiogenesis and metastasis. FASEB J 17(12): 1771-1773, 2003. PMID: 12958205. DOI: 10.1096/fj.02-1129fje

49 Guzmán M, Duarte MJ, Blázquez C, Ravina J, Rosa MC, GalveRoperh I, Sánchez C, Velasco G and González-Feria L: A pilot clinical study of Delta9-tetrahydrocannabinol in patients with recurrent glioblastoma multiforme. Br J Cancer 95(2): 197-203, 2006. PMID: 16804518. DOI: 10.1038/sj.bjc.6603236

50 Massi P, Vaccani A, Bianchessi S, Costa B, Macchi P and Parolaro D: The non-psychoactive cannabidiol triggers caspase activation and oxidative stress in human glioma cells. Cell Mol Life Sci 63(17): 2057-2066, 2006. PMID: 16909207. DOI: 10.1007/s00018-006-6156-X

51 Siegel RL, Miller KD and Jemal A: Cancer statistics, 2016. CA Cancer J Clin 66(1): 7-30, 2016. PMID: 26742998. DOI: $10.3322 /$ caac. 21332
52 Sarkar FH, Banerjee $\mathrm{S}$ and $\mathrm{Li} \mathrm{Y}$ : Pancreatic cancer: pathogenesis, prevention and treatment. Toxicol Appl Pharmacol 224(3): 326-336, 2007. PMID: 17174370. DOI: 10.1016/j.taap. 2006.11.007

53 Tang SC and Chen YC: Novel therapeutic targets for pancreatic cancer. World J Gastroenterol 20(31): 10825-10844, 2014. PMID: 25152585. DOI: 10.3748/wjg.v20.i31.10825

54 Iovanna J, Mallmann MC, Gonçalves A, Turrini O and Dagorn JC: Current knowledge on pancreatic cancer. Front Oncol 2: 6, 2012. PMID: 22655256. DOI: 10.3389/fonc.2012.00006

55 Hill R, Rabb M, Madureira PA, Clements D, Gujar SA, Waisman DM, Giacomantonio CA and Lee PW: Gemcitabine-mediated tumour regression and p53-dependent gene expression: implications for colon and pancreatic cancer therapy. Cell Death Dis 4: e791, 2013. PMID: 24008735. DOI: 10.1038/cddis. 2013.307

56 Algül H, Treiber M, Lesina M and Schmid RM: Mechanisms of disease: chronic inflammation and cancer in the pancreas - a potential role for pancreatic stellate cells? Nat Clin Pract Gastroenterol Hepatol 4(8): 454-462, 2007. PMID: 17667994. DOI: $10.1038 /$ ncpgasthep0881

57 Danovi SA, Wong HH and Lemoine NR: Targeted therapies for pancreatic cancer. Br Med Bull 87: 97-130, 2008. PMID: 18753179. DOI: $10.1093 / \mathrm{bmb} / \mathrm{ldn} 027$

58 Damaskos C, Garmpis N, Karatzas T, Kostakis ID, Nikolidakis L, Kostakis A and Kouraklis G: Nuclear receptors in pancreatic tumor cells. Anticancer Res 34(12): 6897-6911, 2014. PMID: 25503115.

59 Cowley MJ, Chang DK, Pajic M, Johns AL, Waddell N, Grimmond SM and Biankin AV: Understanding pancreatic cancer genomes. J Hepatobiliary Pancreat Sci 20(6): 549-556, 2013. PMID: 23660961. DOI: 10.1007/s00534-013-0610-6

60 Fogli S, Nieri P, Chicca A, Adinolfi B, Mariotti V, Iacopetti P, Breschi MC and Pellegrini S: Cannabinoid derivatives induce cell death in pancreatic MIA PaCa-2 cells via a receptorindependent mechanism. FEBS Lett 580(7): 1733-1739, 2006. PMID: 16500647. DOI: 10.1016/j.febslet.2006.02.024

61 Michalski CW, Oti FE, Erkan M, Sauliunaite D, Bergmann F, Pacher P, Batkai S, Müller MW, Giese NA, Friess H and Kleeff $\mathrm{J}$ : Cannabinoids in pancreatic cancer: correlation with survival and pain. Int J Cancer 122(4): 742-750, 2008. PMID: 17943729. DOI: $10.1002 / \mathrm{ijc} .23114$

62 Guo X, Ling X, Du F, Wang Q, Huang W, Wang Z, Ding X, Bai $\mathrm{M}$ and $\mathrm{Wu} \mathrm{Z}$ : Molecular imaging of pancreatic duct adenocarcinoma using a type 2 cannabinoid receptor-targeted near-infrared fluorescent probe. Transl Oncol 11(5): 1065-1073, 2018. PMID: 30005208. DOI: 10.1016/j.tranon.2018.06.009

63 Luongo M, Marinelli O, Zeppa L, Aguzzi C, Morelli MB, Amantini C, Frassineti A, di Costanzo M, Fanelli A, Santoni G and Nabissi M: Cannabidiol and oxygen-ozone combination induce cytotoxicity in human pancreatic ductal adenocarcinoma cell lines. Cancers (Basel) 12(10): 2774, 2020. PMID: 32992648. DOI: $10.3390 /$ cancers 12102774

64 Sánchez C, de Ceballos ML, Gomez del Pulgar T, Rueda D, Corbacho C, Velasco G, Galve-Roperh I, Huffman JW, Ramón y Cajal S and Guzmán M: Inhibition of glioma growth in vivo by selective activation of the $\mathrm{CB}(2)$ cannabinoid receptor. Cancer Res 61(15): 5784-5789, 2001. PMID: 11479216.

65 McKallip RJ, Lombard C, Fisher M, Martin BR, Ryu S, Grant S, Nagarkatti PS and Nagarkatti M: Targeting CB2 cannabinoid 
receptors as a novel therapy to treat malignant lymphoblastic disease. Blood 100(2): 627-634, 2002. PMID: 12091357. DOI: 10.1182/blood-2002-01-0098

66 Donadelli M, Dando I, Zaniboni T, Costanzo C, Dalla Pozza E, Scupoli MT, Scarpa A, Zappavigna S, Marra M, Abbruzzese A, Bifulco M, Caraglia M and Palmieri M: Gemcitabine/cannabinoid combination triggers autophagy in pancreatic cancer cells through a ROS-mediated mechanism. Cell Death Dis 2: e152, 2011. PMID: 21525939. DOI: 10.1038/cddis.2011.36

67 Krylatov AV, Maslov LN, Lasukova OV and Pertwee RG: Cannabinoid receptor antagonists SR141716 and SR144528 exhibit properties of partial agonists in experiments on isolated perfused rat heart. Bull Exp Biol Med 139(5): 558-561, 2005. PMID: 16224548 . DOI: $10.1007 / \mathrm{s} 10517-005-0344-9$

68 Aizikovich A: Anticancer effect of new cannabinoids derived from tetrahydrocannabinolic acid on PANC-1 and AsPC-1 human pancreas tumor cells. J Pancreat Cancer 6(1): 40-44, 2020. PMID: 32642629. DOI: 10.1089/pancan.2020.0003

69 Puthalakath H, O'Reilly LA, Gunn P, Lee L, Kelly PN, Huntington ND, Hughes PD, Michalak EM, McKimm-Breschkin J, Motoyama N, Gotoh T, Akira S, Bouillet P and Strasser A: ER stress triggers apoptosis by activating $\mathrm{BH} 3$-only protein Bim. Cell 129(7): 1337-1349, 2007. PMID: 17604722. DOI: 10.1016/ j.cell.2007.04.027

70 Schönthal AH: Endoplasmic reticulum stress and autophagy as targets for cancer therapy. Cancer Lett 275(2): 163-169, 2009. PMID: 18692955. DOI: 10.1016/j.canlet.2008.07.005

71 Brandi J, Dando I, Palmieri M, Donadelli M and Cecconi D: Comparative proteomic and phosphoproteomic profiling of pancreatic adenocarcinoma cells treated with $\mathrm{CB} 1$ or $\mathrm{CB} 2$ agonists. Electrophoresis 34(9-10): 1359-1368, 2013. PMID: 23463621. DOI: 10.1002/elps.201200402

72 Pan H, Yang K, Zhang J, Xu Y, Jiang Y, Yuan Y, Zhang X and $\mathrm{Xu}$ W: Design, synthesis and biological evaluation of novel Lisoserine tripeptide derivatives as aminopeptidase $\mathrm{N}$ inhibitors. J Enzyme Inhib Med Chem 28(4): 717-726, 2013. PMID: 22545941. DOI: 10.3109/14756366.2012.680062

73 Pei KL, Yuan Y, Qin SH, Wang Y, Zhou L, Zhang HL, Qu XJ and Cui SX: CIP-13F, a novel aminopeptidase N (APN/CD13) inhibitor, inhibits Lewis lung carcinoma growth and metastasis in mice. Cancer Chemother Pharmacol 69(4): 1029-1038, 2012. PMID: 22186885. DOI: 10.1007/s00280-011-1799-1

74 Ikeda N, Nakajima Y, Tokuhara T, Hattori N, Sho M, Kanehiro $\mathrm{H}$ and Miyake $\mathrm{M}$ : Clinical significance of aminopeptidase $\mathrm{N} / \mathrm{CD} 13$ expression in human pancreatic carcinoma. Clin Cancer Res 9(4): 1503-1508, 2003. PMID: 12684426.

$75 \mathrm{Ku} \mathrm{NO}$ and Omary MB: Identification of the major physiologic phosphorylation site of human keratin 18: potential kinases and a role in filament reorganization. J Cell Biol 127(1): 161-171, 1994. PMID: 7523419. DOI: 10.1083/jcb.127.1.161

$76 \mathrm{Ku} \mathrm{NO}$, Liao J and Omary MB: Phosphorylation of human keratin 18 serine 33 regulates binding to $14-3-3$ proteins. EMBO J 17(7): 1892-1906, 1998. PMID: 9524113. DOI: 10.1093/ emboj/17.7.1892

77 Schutte B, Henfling M, Kölgen W, Bouman M, Meex S, Leers MP, Nap M, Björklund V, Björklund P, Björklund B, Lane EB, Omary MB, Jörnvall $\mathrm{H}$ and Ramaekers FC: Keratin 8/18 breakdown and reorganization during apoptosis. Exp Cell Res 297(1): 11-26, 2004. PMID: 15194421. DOI: 10.1016/j.yexcr. 2004.02.019
78 Fleming A, Noda T, Yoshimori T and Rubinsztein DC: Chemical modulators of autophagy as biological probes and potential therapeutics. Nat Chem Biol 7(1): 9-17, 2011. PMID: 21164513. DOI: $10.1038 /$ nchembio. 500

79 Vara D, Salazar M, Olea-Herrero N, Guzmán M, Velasco G and Díaz-Laviada I: Anti-tumoral action of cannabinoids on hepatocellular carcinoma: role of AMPK-dependent activation of autophagy. Cell Death Differ 18(7): 1099-1111, 2011. PMID: 21475304. DOI: $10.1038 / \mathrm{cdd} .2011 .32$

80 Dando I, Donadelli M, Costanzo C, Dalla Pozza E, D'Alessandro A, Zolla L and Palmieri M: Cannabinoids inhibit energetic metabolism and induce AMPK-dependent autophagy in pancreatic cancer cells. Cell Death Dis 4: e664, 2013. PMID: 23764845. DOI: $10.1038 /$ cddis.2013.151

81 Wang S, Song P and Zou MH: AMP-activated protein kinase, stress responses and cardiovascular diseases. Clin Sci (Lond) 122(12): 555-573, 2012. PMID: 22390198. DOI: 10.1042/ CS20110625

82 Lamberts RR, Onderwater G, Hamdani N, Vreden MJ, Steenhuisen J, Eringa EC, Loer SA, Stienen GJ and Bouwman RA: Reactive oxygen species-induced stimulation of 5'AMP-activated protein kinase mediates sevoflurane-induced cardioprotection. Circulation 120(11 Suppl): S10-S15, 2009. PMID: 19752353. DOI: 10.1161/CIRCULATIONAHA.108.828426

83 Yang Y, Huynh N, Dumesny C, Wang K, He H and Nikfarjam $\mathrm{M}$ : Cannabinoids inhibited pancreatic cancer via $\mathrm{P}-21$ activated kinase 1 mediated pathway. Int J Mol Sci 21(21): 8035, 2020. PMID: 33126623. DOI: 10.3390/ijms21218035

84 Aquila S, Guido C, Santoro A, Perrotta I, Laezza C, Bifulco M and Sebastiano A: Human sperm anatomy: ultrastructural localization of the cannabinoid1 receptor and a potential role of anandamide in sperm survival and acrosome reaction. Anat Rec (Hoboken) 293(2): 298-309, 2010. PMID: 19938110. DOI: 10.1002/ar.21042

85 Cairns RA, Harris IS and Mak TW: Regulation of cancer cell metabolism. Nat Rev Cancer 11(2): 85-95, 2011. PMID: 21258394. DOI: $10.1038 / \mathrm{nrc} 2981$

86 David CJ, Chen M, Assanah M, Canoll P and Manley JL: HnRNP proteins controlled by c-Myc deregulate pyruvate kinase mRNA splicing in cancer. Nature 463(7279): 364-368, 2010. PMID: 20010808. DOI: 10.1038/nature08697

87 Hitosugi T, Kang S, Vander Heiden MG, Chung TW, Elf S, Lythgoe K, Dong S, Lonial S, Wang X, Chen GZ, Xie J, Gu TL, Polakiewicz RD, Roesel JL, Boggon TJ, Khuri FR, Gilliland DG, Cantley LC, Kaufman $\mathrm{J}$ and Chen J: Tyrosine phosphorylation inhibits PKM2 to promote the Warburg effect and tumor growth. Sci Signal 2(97): ra73, 2009. PMID: 19920251. DOI: $10.1126 /$ scisignal.2000431

88 Yasmin-Karim S, Moreau M, Mueller R, Sinha N, Dabney R, Herman A and Ngwa W: Enhancing the therapeutic efficacy of cancer treatment with cannabinoids. Front Oncol 8: 114, 2018. PMID: 29740535. DOI: 10.3389/fonc.2018.00114

89 Lowe H, Toyang N, Steele B, Bryant J and Ngwa W: The endocannabinoid system: a potential target for the treatment of various diseases. Int J Mol Sci 22(17): 9472, 2021. PMID: 34502379. DOI: $10.3390 /$ ijms 22179472

Received June 25, 2021

Revised December 12, 2021

Accepted December 18, 2021 